\title{
PENGARUH ANALISIS KREDIT TERHADAP PEMBIAYAAN BERMASALAH (KREDIT MACET) PADA PT BANK PEMBIAYAAN RAKYAT SYARIAH ARTHA MADANI CIKARANG, JAWA BARAT
}

\author{
Tavitri Rangkuti \\ Institut Ilmu Sosial dan Manajemen STIAMI \\ Tavitri.rangkuti@stiami.ac.id
}

\section{ARTIKEL INFO}

ABSTRACT

eywords: Analysis, Troubled Financing (Bad Debt)
Credit is a risky business, where there is a possibility of credit being given uncollectible (bad credit). Debtors (credit recipients) can present a million reasons for not paying their obligations. On the other hand the bank must pay every rupiah of public funds placed on it. The bank can not say that the loans it provides are not collectible, the public funds can not be paid. In this regard, banks should only provide financing (credit) to the appropriate debtor. The bank must be able to control the credit risk it provides. The Bank developed a selection process to screen each proposed credit (proposed financing) proposal. In giving credit, the bank must have the trust to the prospective debtor as well as the debtor has the confidence to save the funds in the bank. Funds provided will be used in accordance with the objectives and will eventually be returned to the bank in accordance with the agreed agreement. This credit grant has a high enough risk factor and has a significant effect on Bank soundness. Therefore, PT BPRS (Islamic Loan Bank) Artha Madani analyzes credit well before approving financing for prospective borrowers and gives attention to various aspects related to financing processing.

This type of research is associative. Data Collection Technique is done by Library Study and Field Study. Sampling technique is based on the provisions of percentage according to Suharsini Arikunto (1993: 120). Total population The number of employees of PT BPRS Artha Madani is 53 people, so the sample is taken as many as 15 people. Data Analysis Technique is calculated by using the average value of Likert scale, correlation coefficient and determination.

From the results of research, it is found that the magnitude of responses of respondents to variable credit analysis indicates a number of 4.01 which means credit analysis on PT BPRS Artha Madani has been running well. The coefficient $r$ obtained is 0.728 and this value shows the relationship of variable $x$ (credit analysis) with variable $y$ (financing approval) is strong.

\section{PENDAHULUAN}

Perkembangan ekonomi Islam di Indonesia ditandai dengan perkembangan bank dan lembaga keuangan syariah. Kebijakan pemerintah terhadap perbankan syariah di Indonesia terdapat dalam Undang-Undang Perbankan No.7 tahun 1992 tentang Perbankan dan Undang-Undang No. 10 tahun 1998. Bank adalah bisnis yang unik. Mereka melakukan bisnis dengan menggunakan dana orang lain (other people's money). Neraca pada laporan keuangan menunjukan bahwa sumber pembiayaan utama untuk kredit tersebut adalah DPK (Dana Pihak Ketiga) tabungan, deposito dan lain-lain.

Bagi masyarakat yang hidup di negara-negara maju, seperti negara-negara eropa, amerika dan jepang kata bank sudah bukan merupakan barang yang asing. Bank sudah merupakan mitra dalam rangka memenuhi semua kebutuhan keuangan. Bank dijadikan sebagai tempat untuk melakukan berbagai transaksiyang berhubungan dengan keuangan seperti, tempat mengamankan uang, melakukan investasi, pengiriman uang, melakukan pembayaran atua melakukan penagihan. 
Bank adalah badan usaha yang menghimpun dana dari masyrakat dalam bentuk simpanan dan menyalurkannya kepada masyarakat dalam bentuk kredit atau dalam bentuk lainnya dalam rangka meningkatkan taraf hidup rakyat banyak. Perbankan syariah dikenal sebagai bank yang tidak menerapkan sistem bunga seperti bank konvensional. Bank syariah menerapkan sistem bagi hasil yang tidak saja berdimensi material belaka tetapi juga dituntut unsur inmaterialnya. Prinsip utama bank syariah adalah harus menuju pada pengembangan kesejahteraan masyarakat yang bermuara kepada kondisi sosial masyarakat yang bersifat menentramkan.

Dalam sejarahnya kegiatan perbankan dikenal mulai zaman Babylonia. Kegiatan perbankan ini kemudian berkembang ke zaman Yunani kuno serta zaman Romawi. Pada saat itu kegiatan utama bank hanyalah sebagai tempat tukar menukar uang oleh para pedagang antar kerajaan. Seiring dengan pekembangan dunia, maka perkembangan perbankanpun semakin pesat.

Pada saat krisis moneter yang dialami oleh Indonesia pada tahun 1997 megakibatkan beberapa bank dilikuidasi. Sehingga timbul krisis kepercayaan masyarakat terhadap bank. Terbukti dengan nasabah terdorong untuk menarik dana mereka secara besar-besaran (rush) dari perbankan nasional. Dengan adanya kemungkinan likuidasi lanjutan yang akan membahayakan keamanan dana yang mereka simpan.

Kredit adalah bisnis yang berisiko, dimana ada kemungkinan kredit yang diberikan tidak dapat tertagih (kredit macet). Debitur (penerima kredit) dapat mengemukakan sejuta alasan untuk tidak membayar kewajibannya. Disisi lain bank harus membayar setiap rupiah dana masyarakat yang ditempatkan padanya. Bank tidak dapat mengatakan bahwa kredit yang diberikannya tidak tertagih, maka dana masyarakat belum dapat dibayar. Sehubungan dengan hal tersebut, sudah seharusnya bank hanya memberikan pembiayaan (kredit) kepada debitur yang layak. Bank harus dapat mengendalikan risiko kredit yang diberikannya. Bank mengembangkan suatu proses seleksi untuk menyaring setiap proposal kredit (usulan pembiayaan) yang masuk.

Dalam memberikan kredit, bank harus mempunyai kepercayaan terhadap calon debitur seperti halnya debitur mempunyai kepercayaan untuk menyimpan dananya di bank. Dana yang diberikan akan digunakan sesuai dengan tujuan dan pada akhirnya akan dikembalikan lagi kepada bank sesuai dengan perjanjian yang telah disepakati. Pemberian kredit ini memiliki faktor risiko yang cukup tinggi dan berpengaruh cukup besar terhadap tingkat kesehatan Bank. Oleh karena itu, PT BPRS ( Bank Pembiayaan Syariah ) Artha Madani menganalisis kredit dengan baik sebelum menyetujui pembiayaan bagi calon debitur dan memberikan perhatian terhadap berbagai aspek yang berkaitan dengan pengolahan pembiayaan.

PT BPRS Artha Madani adalah Bank Pembiayaan Rakyat Syariah yang terkemuka di Cikarang. PT BPRS Artha Madani melayani jasa keuangan menyalurkan dana dan menyimpan dana masyarkat yang bekerjasama dengan LPS (Lembaga Penjaminan Simpanan). PT BPRS Artha Madani lebih memfokuskan pada pembiayaan dikarenakan pangsa pasar di daerah bekasi lebih banyak membutuhkan dana. Strategi pemasaran BPRS Artha Madani pada pembiayaan kolektif dan obyeknya lebih ke Pegawai Negeri Sipil (PNS) dan Usaha Kecil Menengah (UKM).

Bank harus dapat mengendalikan risiko kredit yang diberikan. Untuk itu, bank mengembangkan suatu proses seleksi untuk menyaring setiap proposal kredit yang masuk. Dalam buku Jopie Jusuf dikatakan setiap proposal kredit yang masuk akan dianalisis dengan teliti. Bila memenuhi syarat, baru diadakan dokumentasi (pengikatan kredit dan jaminan). Dalam analisis kredit, apabila proposal dinyatakan layak tetapi terdapat masalah yang dapat membahayakan bank, maka kredit tersebut harus dihentikan. Setelah dokumentasi lengkap bank mengadakan pencairan dana (disbursement) sesuai perjanjian kredit. Dalam pencairan dana maka bank harus pula berhati-hati dimana debitur harus melengkapi syarat tertentu sebelum pencairan dana tersebut. Setelah kredit dicairkan bank harus terus-menerus melakukan pemantauan atas kredit yan diberikan dan mengikuti pekembangan bisnis nasabah dan berbagai aspek yang mungkin memengaruhi kualitas dari kredit tersebut.

Atas dasar itulah penulis tertarik untuk mengetahui :

a. Persyaratan apa saja yang harus dipenuhi calon debitur dalam mengajukan pembiayaan?

b. Bagaimana prosedur pembiayaan pada PT BPRS Artha Madani?

c. Produk atau jenis pembiayaan apa saja pada PT BPRS Artha Madani?

d. Bagaimana aspek-aspek penilaian pembiayaan pada PT BPRS Artha Madani?

e. Bagaimanakah analisis pembiayaan yang diterapkan pada PT BPRS Artha Madani di Cikarang? 
f. Seberapa kuat hubungan analisis kredit (pembiayaan) terhadap persetujuan pembiayaan pada PT BPRS Artha Madani di Cikarang?

g. Bagaimanakah jika debitur melakukan pengembalian kredit sebelum jatuh tempo?

\section{KAJIAN PUSTAKA}

\section{Kredit}

Menurut Kasmir (2003:101) Kredit berasal dari bahasa latin disebut "credere" yang artinya percaya. Kepercayaan dilihat dari sisi bank adalah suatu keyakinan bahwa yang diberikan akan dapat dikembalikan tepat pada waktunya sesuai dengan kesepakatan kedua belah pihak yang terutang dalam akte perjanjian kredit. Oleh karena itu, untuk meyakinkan bank bahwa nasabah dapat dipercaya sebelum kredit diberikan terlebih dahulu bank mengadakan anlaisis kredit. Analisis kredit mencakup latar belakang nasabah dan perusahaan, prospek usahanya, jaminan yang diberikan serta faktor-faktor lainnya. Tujuan analisis kredit agar bank yakin bahwa kredit yang diberikan aman. Dala buku " Analisis Kredit untuk Account Officer" Kredit adalah bisnis yang berisiko, dimana ada kemungkinan kredit yang diberikan tidak dapat tertagih (kredit macet). Debitur (penerima kredit) dapat mengemukakan sejuta alasan. Pemberian kredit tanpa dianalisis terlebih dahulu akan sangat membahayakan bank. Nasabah dalam hal ini dengan mudah memberikan data-data fiktif, sehingga kredit sebenarnya tidak layak, tetapi telah dilakukan persetujuan kredit (pembiayaan) kepada debitur. Faktor salah analisis ini bukanlah bukanlah merupakan penyebab utama kredit macet. Penyebab lainnya mungkin disebabkan oleh musibah maupun bencana alam.

Pengertian kredit menurut Undang-Undang Perbankan Nomor 10 tahun 1998 adalah penyediaan uang atau tagihan yang dapat dipersamakan dengan itu, berdasarkan persetujuan atau kesepakatan pinjam meminjam antara bank dengan pihak lain yang mewajibkan pihak peminjam melunasi utangnya setelah jangka waktu tertentu dengan pemberian bunga. Sedangkan pengertian pembiayaan adalah penyediaan uang atau tagihanyang dapat dipersamakan dengan itu, berdasarkan persetujuan atau kesepakatan antara bank dengan pihak lain yang mewajibakan pihak yang dibiayai untuk mengembalikan uang atau tagihan tersebut setelah jangka waktu tertentu dengan imbalan atau bagi hasil. Kredit atau pembiayaan dapat berupa uang atau tagihan yang nilainya dapat diukur dengan uang. Yang menjadi perbedaan antara kredit yang diberikan oleh bank berdasarkan konvensional dengan pembiayaan yang diberikan oleh bank berdasarkan prinsip syariah adalah terletak pada keuntungan yang diharapkan. Bagi bank berdasarkan prinsip konvensional keuntungan yang diperoleh melalui bunga, sedangkan bagi bank yang berdasarkan prinsip syariah berupa imbalan atau bagi hasil.

Adapun unsur-unsur yang terkandung dalam pemberian suatu fasilitas kredit adalah sebagai berikut:

1. Kepercayaan

Kepercayaan merupakan suatu keyakinan bagi pemberi kredit bahwa kredit yang diberikan berupa uang, barang atau jasa. Sebelum kredit disetujui untuk dikucurkan ke debitur harus dilakukan penelitian dan penyelidikan tentang kondisi nasabah baik intern maupun ekstern. Untuk menilai kesungguhan dan itikad baik nasabah terhadap bank.

2. Kesepakatan

Kesepakatan ini dituangkan dalam suatu perjanjian dimana masing-masing pihak menandatangani hak dan kewajibannya. Kesepakatan ini kemudian dituangkan dalam akad kredit dan ditangani kedua belah pihak sebelum kredit disetujui.

3. Jangka Waktu

Setiap kredit yang diberikan memiliki jangka waktu tertentu, jangka waktu ini mencakup masa pengembalian kredit yang telah disepakati. Jangka waktu merupakan batas waktu pengembalian angsuran kredit yang sudah disepakati kedu belah pihak.

4. Risiko

Akibat adanya tenggang waktu, maka pengembalian kredit akan memungkinkan suatu risiko tidak tertagihnya atau macet. Semakin panjang suatu jangka waktu kredit, maka semakin besar risikonya. Risiko ini menjadi tanggungan bank baik risiko yang disengaja maupun yang tidak disengaja.

5. Balas Jasa

Bagi bank balas jasa merupakan keuntungan atau pendapatan atas pemberian suatu kredit. Bagi bank yang berdasarkan prinsip syariah balas jasanya ditentukan bagi hasil. 


\section{Penilaian, Prosedur dan Penyelesaian Kredit Macet}

Penilaian kredit adalah suatu kegiatan pemeriksaan, penelitian, dan analisis terhadap kelengkapan, keabsahan dan kelayakan berkas atau data permohonan kredit calon debitur hingga dikeluarkannya suatu keputusan apakah kredit tersebut diterima atau ditolak. (Djohan 2000:97).

Menurut Thomas Suyatno, dkk (2003:70) yang dimaksud dengan analisis kredit adalah pekerjaan yang meliputi:

a. Mempersiapkan pekerjaan penguraian dari segala aspek, baik keuangan maupun non keuangan untuk mengetahui kemungkinan dapat atau tidak dapat dipertimbangkan suatu permohonan kredit.

b. Menyusun laporan analisis yang diperlukan yang berisi penguraian dan kesimpulan serta penyajian alternatif sebagai bahan pertimbangan untuk pengambilan keputusan pimpinan dari permohonan kredit nasabah.

Menurut Kasmir (2003:117) dalam melakukan penilaian biasanya kriterian penilaian yang umum dan harus dilakukan oleh bank untuk mendapatkan nasabah yang benar-benar layak untuk diberikan dilakukan dengan analisis 5C dan 7P.

Penilaian dengan analisis $5 \mathrm{C}$ adalaha sebagai berikut:

\section{Character}

Character merupakan sifat atau watak seseorang. Sifat atau watak dari orang-orang yang akan diberikan kredit harus dapat dipercaya. Untuk membaca watak atau sifat dari calon debitur dapat dilihat dari latar belakang nasabah, baik yang bersifat latar belakang pekerjaan maupun yang bersifat pribadi. Dari sifat dan watak ini dapat dijadikan suatu ukuran tentang kemauan nasabah untuk membayar.

2. Capacity

Capacity adalah analisis untuk mengetahui kemampuan nasabah dalam membayar kredit. Drai penilaian ini dapat dilihat kemampuan nasabah dalam mengelola bisnis. Kemampuan ini dapat dihubungkan dengan latar belakang pendidikan dan pengalamannya selama ini dalam mengelola usahanya, sehingga akan terlihat kemampuannya dalam mengembalikan kredit yang disalurkan.

3. Capital

Untuk melihat penggunaan modal apakah efektif atau tidak, dapat dilihat dari laporan keuangan yang disajikan dengan melakukan pengukuran seperti dari segi likuiditas, solvabilitas, rentabilitas dan ukuran lainnya. Analisis capital juga harus menganalisis dari sumber manasaja modal yang ada sekarang ini, termasuk presentase modal yang digunakan untuk membiayai proyek yang akan dijalankan berapa modal sendiri dan berapa modal pinjaman.

4. Condition

Dalam menilai kredit hendaknya juga dinilai kondisi ekonomi, sosial dan politik yang ada sekarang dan prediksi untuk di masa yang akan datang. Penilaian kondisi atau prospek bidang usaha yang dibiayai hendaknya benar-benar memiliki prospek yang baik, sehingga tersebut bermasalah relatif kecil.

5. Collateral

Merupakan jaminan yang diberikan calon nasabah baik yang bersifat fisik maupun non fisik. Jaminan hendaknya melebihi jumlah kredit yang diberikan. Jaminan juga harus diteliti keabsahan dan kesempurnaannya, sehingga jika terjadi suatu masalah, maka jaminan yang dititipkan akan dapt dipergunakan secepat mungkin.

Selanjutnya penilaian suatu kredit dapat pula dilakukan dengan analisis 7P kredit dengan unsur penilaian sebagai berikut:

\section{Personality}

Personality adalah menilai nasabah dari segi kepribadiannyaatau tingkah lakunya sehari-hari maupun kepribadiannya masa lalu. Penilaian personality juga mencakup sikap, emosi, tingkah laku dan tindakan nasabah dalam menghadapi suatu masalah dan menyelesaikannnya.

2. Party

Party adalah mengklasifikasikan nasabah kedalam klasifikasi tertentu atau golongan-golongan tertentu, berdasarkan modal, loyalitas serta karakternya. Nasabah yang digolongkan kedalam golongan tertentu akan mendapatkan fasilitas yang berbeda dari bank. 
3. Purpose

Purpose adalah untuk mengetahui tujuan nasabah dalam mengambil kredit, termasukjenis kredit yang diinginkan nasabah. Tujuan pengambilan kredit dapat bermacam-macam sesuai kebutuhan.

4. Prospect

Prospect adalah untuk mengetahui tujuan nasabah dimasa yang akan datang menguntungkan atau tidak atau dengan kata lain mempunyai prospek atau sebaliknya. Hal ini sangat penting menginat jika suatu fasilitas kredit yang dibiayai tanpa mempunyai prospek, bukan hanya bank yang rugi akan tetapi juga nasabah.

5. Payment

Payment merupakanukuran bagaimana cara nasabah mengembalikan kredit yang telah diambil atau dari sumber mana saja dana untuk pengembalian kredit. Semakin banyak sumber penghasilan debitur maka akan semakin baik.

6. Profitability

Untuk menganalisis bagaimana kemampuan nasabah dalam mencari laba. Profitability diukur dari periode ke periode, apakah akan tetap sama atau semakin meningkat, dengan tambahan kredit yang akan diperolehnya.

\section{Protection}

Tujuannya adalah bagaimana menjaga agar kredit yang diberikan mendapat jaminan perlindungan. Kredit yang diberikan benar-benar aman, perlindungan yang diberikan oleh debitur dapat berupa ,jaminan barang atau jaminan asuransi.

Penilaian suatu kredit layak atau tidak untuk diberikan dapat dilakukan dengan menilai seluruh aspek yang ada. Penilaian dengan seluruh aspek yang ada dikenal dengan nama studi kelayakan usaha. Penilaian dengan model ini biasanya digunakan untuk proyek-proyek yang bernilai besar dan berjangka waktu panjang.

Aspek-aspek yang dinilai antara lain meliputi:

1. Aspek Yuridis/Hukum

Yang dinilai dalam aspek ini adalah masalah legalitas badan usaha serta izin-izin yang dimilki perusahaan yang mengajukan kredit. Penilaian dimulai dengan meneliti keabsahan dan kesempurnaan akte pendirian perusahaan. Dokumen dan surat-surat penting yang perlu diteliti seperti:

a. Surat Izin Usaha Industri (SIUI) untuk sektor industri.

b. Surat Izin Usaha Perdagangan (SIUP) untuk sektor perdagangan.

c. Tanda Daftar Perusahaan (TDP).

d. Nomor Pokok Wajib Pajak (NPWP).

e. Keabsahan surat-surat yang dijaminkan misalnya sertifikat tanah dan sertifikat deposito.

f. Serta dokumen-dokumen lainnya, seperti Kartu Tanda Penduduk (KTP).

2. Aspek Pasar dan Pemasaran

Dalam aspek ini yang dinilai adalah besar kecilnya permintaan terhadap produk yang dihasilkan sekarang dan dimasa yang akan datang, maka akan diketahui prospek pemasaran produk tersebut. Yang perlu diteliti dalam aspek ini adalah:

a. Hasil penjualan atau produksi minimal tiga bulan terakhir.

b. Rencana penjualan dan produksi minimal tiga bulan kedepan.

c. Peta kekuatan pesaing yang ada.

d. Prospek produk secara keseluruhan.

3. Aspek Keuangan

Aspek yang dinilai adalah sumber-sumber dana yang dimiliki untuk membiayai usahanya dan bagaimana penggunaan dana tersebut. Disamping itu hendaknya dibuatkan cash flow keuangan perusahaan. Dari cash flow ini akan terlihat pendapatan dan biaya-biaya sehingga dapat dinilai layak atau tidak usaha tersebut.

Penilaian bank dari segi aspek keuangan mencakup antara lain: (a) Rasio Likuiditas ; (b) Rasio Solvabilitas; (c) Rasio Rentabilitas; (d) Payback Period; (e) Net Present Value (NPV); (f) Internal Rate of Return (IRR); (g) Break Even Point (BEP)

4. Aspek Teknis/Operasi 
Merupakan aspek yang membahas masalah yang berkaitan dengan produksi, lokasi dan lay out. Demikian pula dengan masalah lay out gedung, lay out ruangan dan lay out mesin-mesin termasuk jenis mesin dan teknologi yang digunakan.

5. Aspek Manajemen

Aspek ini digunakan untuk menilai struktur organisasi perusahaan sumber daya manusia yang dimiliki serta latar belakang pendidikan dan pengalaman sumber daya manusianya. Pengalaman perusahaan dalam mengelola berbagai prospek yang ada juga menjadi pertimbangan lain.

6. Aspek Sosial Ekonomi

Aspek sosial ekonomi adalah menganalisis dampaknya yang timbul akibat adanya prospek terhadap perekonomian masyarakat dan sosial masyarakat secara umum: (a) Mengurangi pengangguran; (b) Meningkatkan pendapatan masyarakat; (c) Tersedianya sarana dan prasarana.

7. Aspek AMDAL

Amdal atau Analisis Dampak Lingkungan merupakan analisis terhadap lingkungan baik darat, air atau udara termasuk kesehatan manusia apabila prospek tersebut dijalankan. Analisis ini dilakukan secara mendalam sebelum kredit tersebut disalurkan, sehingga proyek yang dibiayai tidak akan mengalami pencemaran lingkungan disekitarnya.

Prosedur pemberian kredit adalah tahap-tahap yang harus dilalui sebelum sesuatu kredit diputuskan untuk disetujui. Tujuannya adalah untuk mempermudah bank dalam menilai kelayakan suatu permohonan kredit. Secara umum prosedur pemberian kredit oleh badan hukum sebagai berikut:

1. Pengajuan berkas-berkas

Dalam hal ini pemohon kredit mengajukan permohonan kredit yang dituangkan dalam suatu proposal usulan pembiayaan. Kemudian dilampiri dengan berkas-berkas lainnya yang dibutuhkan.

a. Pengajuan proposal hendaknya berisi latar belakang perusahaan, maksud dan tujuan mengajukan pembiayaan, Besarnya kredit dan jangka waktu pembiayaan.

b. Melampirkan dokumen-dokumen yang meliputi fotokopi akte notaris, Tanda Daftar Perusahaan, Nomor Pokok Wajib Pajak, Neraca dan laporan rugi laba tiga tahun terakhir, bukti diri dari pimpinan perusahaan, dan sertifikat jaminan.

c. Penilaian dapat dilakukan dari neraca dan rugi laba.

2. Penyelidikan berkas pinjaman

Tujuannya adalah untuk mengetahui apakah berkas yang diajukan sudah lengkap sesuai persyaratan dan menyelidiki keabsahan berkas. Jika pihak perbankan belum menyetujui karena belum lengkap, maka nasabah diminta untuk segera melengkapinya.

3. Wawancara

Merupakan penyelidikan kepada calon peminjam dengan langsung berhadapan dengan calon peminjam. Tujuannya adalah untuk meyakinkan bank bahwa berkas sudah lengkap dan untuk mengetahui keinginan atu kebutuhan nasabah.

4. On the spot

Merupakan kegiatan pemeriksaan kelapangan dengan meninjau berbagai obyek yang akan dijadikan usaha atau jaminan. Sehingga yang dilihat di lapangan sesuai dengan apa yang dikatakan nasabah.

5. Keputusan kredit

Keputusan kredit dalam hal ini adalah untuk menentukan kredit akan diberikan atau ditolak. Keputusan kredit yang akan diumumkan mencakup:

a. Jumlah uang yang diterima.

b. Jangka waktu kredit.

c. Biaya administrasi yang harus dibayar.

d. Waktu pencairan kredit.

Keputusan kredit biasanya merupakan keputusan tim. Begitu pula bagi kredit yang ditolak hendaknya dikirim surat penolakan sesuai dengan alasannya.

6. Penandatanganan akad kredit

Kegiatan ini merupakan kelanjutan dari diputuskannya kredit, maka sebelum kredit dicairkan calon nasabah menandatangani akad kredit, mengikat jaminandan surat perjanjian atau pernyataan yang dianggap perlu. Penandatangan dilaksanakan antara bank dengan debitur secara langsung atau dengan melalui notaris. 
7. Realisasi kredit

Realisasi kredit yang diberikan setelah penandatanganan akad kredit dan surat-surat yang diperlukan dengan membuka rekening tabungan di bank yang bersangkutan.

8. Penyaluran/penarikan dana

Penarikan dana adalah pencairan atau pengambilan uang dari rekening sebagai realisasi dari pemberian kredit dan dapat diambil sesuai ketentuan dan tujuan kredit sekaligus atau bertahap.

Pemberian suatu fasilitas kredit mengandung suatu risiko kemacetan. Akibatnya, kredit tidak dapat ditagih sehingga menimbulkan kerugian yang harus ditanggung oleh bank. Sebelum pencairan dilakukan analis kredit dalam menganalisis setiap permohonan kredit, kemungkinan kredit macet pasti akan ada. Dalam praktiknya kemacetan suatu kredit disebabkan oleh dua unsur sebagai berikut:

1. Dari pihak Perbankan

Dalam melakukan analisis, pihak analis kurang teliti apa yang terjadi tidak diprediksi sebelumnya atau mungkin salah dalam melakukan perhitungan. Dapat pula terjadi dari pihak analis kredit dengan pihak debitur dalam analisisnya dilakukan secara subyektif.

2. Dari pihak Nasabah

Dari pihak nasabah kemacetan kredit dapat dilakukan akibat 2 hal yaitu:

a. Adanya unsur kesengajaan, dalam hal ini nasabah sengaja untuk tidak bermaksud membayar kewajibannya kepada bank sehingga kredit yang diberikan macet. Tidak adanya unsur kemauan untuk membayar.

b. Adanya unsur tidak sengaja, debitur mau membayar akan tetapi tidak mampu. Kredit yang dibiayai mengalami musibah seperti kebakaran, kebanjiran atau kehilangan, sehingga kemampuan ;untuk membayar kredit tidak ada.

Dalam hal kredit macet pihak bank perlu melakukan penyelamatan, sehingga tidak akan menimbulkan kerugian. Penyelamatan yang dilakukan dengan memberikan keringanan berupa jangka waktu atau angsuran terutama bagi kredit terkena musibah atau melakukan penyitaan bagi kredit yang sengaja untuk tidak membayar kewajibannya. Terhadap kredit yang mengalami kemacetan sebaiknya dilakukan penyelamatan sehingga bank tidak mengalami kerugian.

Penyelamatan terhadap kredit macet dilakukan dengan cara antara lain:

1. Rescheduling

Suatu tindakan yang diambil dengan cara memperpanjang jangka waktu kredit atau jangka waktu angsuran. Dalam hal ini debitur diberikan keringanan dalam masalah jangka waktu kredit pembayaran kredit, jangka waktu kredit dari satu tahun menjadi dua tahun sehingga debitur mempunyai waktu yang lebih lama untuk mengembalikannya. Memperpanjang angsuran hampir sama dengan jangka waktu kredit. Dalam hal ini jangka waktu angsuran dari tiga puluh enam kali menjadi empat puluh delapan kali dan jumlah angsuran menjadi mengecil dengan penambahan jumlah angsuran.

2. Reconditioning

Reconditioning adalah bank mengubah berbagai persyaratan yang ada seperti:

a. Kapitalisasi bunga, yaitu bunga dijadikan hutang pokok.

b. Penundaan pembayaran bunga sampai waktu tertentu.

c. Penurunan suku bunga.

d. Pembebasan bunga.

3. Retructuring

Retructuring adalah tindakan bank kepada nasabah dengan cara menambah modal nasabah dengan pertimbangan nasabah memang membutuhkan tambahan dana dan usaha yang dibiayai memang masih layak. Tindakan ini dengan menambah jumlah kredit atau menambah equity.

4. Kombinasi

Merupakan kombinasi dari ketiga jenis, debitur dapat diselamatkan dengan kombinasi antara rescheduling dengan restructuring, jangka waktu diperpanjang pembayaran bunga ditunda atau reconditioning dengan rescheduling jangka waktu diperpanjang modal ditambah.

5. Penyitaan Jaminan

Penyitaan jaminan merupakan jalan terakhir apabila nasabah sudah benar-benar tidak punya itikad baik ataupun sudah tidak mampu lagi untuk membayar semua hutang-hutangnya. 


\section{Kerangka Pemikiran dan Model Penelitian}

Kerangka pemikiran yang diuaraikan diatas, digambarkan dalam bentuk bagan seperti dibawah ini :

\section{Gambar 1. Kerangka Pemikiran}

\begin{tabular}{|c|c|}
\hline $\begin{array}{l}\quad \text { Variabel X } \\
\qquad \text { (Analisis Kredit) } \\
\text { Indikator: } \\
\text { - Kepercayaan kreditur } \\
\text { - Karakter calon debitur } \\
\text { - Personality debitur } \\
\text { - Aspek keuangan } \\
\text { - Jaminan } \\
\text { - Nilai Jaminan } \\
\text { - Mudah } \\
\text { - Penggunaan pembiayaan } \\
\text { - Cepat } \\
\text { - Akurat }\end{array}$ & $\begin{array}{l}\text { Variabel Y } \\
\text { (Persetujuan pembiayaan) } \\
\text { Indikator: } \\
\text { - } \begin{array}{l}\text { Meningkatkan ketelitian pada } \\
\text { usulan pembiayaan }\end{array} \\
\text { - Melihat itikad baik dari calon } \\
\text { debitur } \\
\text { - Melihat kepribadian calon } \\
\text { debitur } \\
\text { - Menganalis keuangan calon } \\
\text { - Mebitur } \\
\text { - Mensurvei keadaan calon } \\
\text { debitur } \\
\text { - Kemudahan persyaratan untuk } \\
\text { calon debitur } \\
\text { - Penggunaan pembiayaan oleh } \\
\text { calon debitur } \\
\text { - Kecepatan menagani nasabah } \\
\text { - Data dari calon debitur harus } \\
\text { benar } \\
\text { - Prosedur pembiayaan }\end{array}$ \\
\hline
\end{tabular}

\section{Hipotesis}

Menurut Soegiyono (2003:70), hipotesis merupakan jawaban sementara terhadap rumusan masalah penelitian, dimana rumusan masalah penelitian telah dinyatakan dalam bentuk kalimat pertanyaan".

Berdasarkan kerangka pemikiran diatas maka penulis menyimpulakan hipotesis terlebih dahulu dan akan diteliti kebenarannya melalui sebuah penelitian, yaitu : "Analisis kredit mempunyai hubungan yang signifikan dengan persetujuan pembiayaan pada PT Bank Pembiayaan Rakyat Syariah Artha Madani".

\section{METODE PENELITIAN}

\section{Jenis Penelitian}

Metode yang digunakan dalam penelitian ini adalah metode assosiatif (hubungan). Menurut Sugiyono (2003 : 11),penelitian assosiatif merupakan penelitian yang bertujuan untuk mengetahui hubungan antara dua variabel atau lebih. Penelitian ini mempunyai tingkatan yang tertinggi bila dibandingkan dengan penelitian deskriptif dan komparatif. Dengan penelitian ini maka akan dapat dibangun suatu teori yang dapat berfungsi untuk menjelaskan, meramalkan dan mengontrol suatu gejala. Dalam penelitian ini, penulis berusaha untuk mengetahui hubungan antara analisis kredit terhadap persetujuan pembiayaan.

\section{Operasionalisasi Variabel}

\section{Definisi Operasional}

Analisis kredit definisi operasionalnya adalah menganalisis dengan teliti dengan penilaian 5C dan 7P. Persetujuan pembiayaan dapat terjadi jika analisis kreditnya baik dan dapat dikucurkan dana kepada debitur. 


\section{Kisi-Kisi Variabel}

Kisi-kisi variabel adalah hasil pemilahan variabel-variabel penelitian. Ada dua macam variabel penalitian yaitu:

\section{a. Variabel Bebas (Independent Variabel)}

Variabel bebas disebut juga variabel yang mempengaruhi. Dalam judul penelitian ini variabel bebas terdapat pada analisis kredit yang mencakup harga pasar. Harga pasar ini dapat memepengaruhi harga jaminan dipasaran. Selain harga pasar juga laporan keuangan dari calon debitur karna laporan keuangan dapat berubah sehingga dapat mempengaruhi variabel dependen atau terikat.

b. Variabel Terikat (Dependent Variabel)

Variabel dependen atau terikat sering juga disebut variabel yang dipengaruhi atau menjadi akibat karena adanya variabel independent (bebas). Dalam judul penelitian ini variabel terikat terdapat pada persetujuan pembiayaan. Persetujuan pembiayaan harus memenuhi kriteria perusahaan dan memenuhi persyaratan yang ada dalam perusahaan.

\section{Teknik Pengumpulan Data}

\section{Studi Kepustakaan}

Yaitu proses pengumpulan data sekunder yang diperoleh melalui sejumlah literatur yang berkaitan dengan permasalahan dalam skripsi ini untuk mendapatkan data teoritis dan melengkapi data-data primer yang diperoleh dari studi lapangan. Literatur yang dapat digunakan seperti buku, bahan kuliah, makalah, laporan-laporan, serta berbagai informasi yang dapat dipertanggung jawabkan. Studi Lapangan

Yaitu proses pengumpulan data primer yang merupakan data inti penelitian dengan cara membagikan pertanyaan tertulis (kuisioner) yang bersifat tertutup. Instrumen penelitian pada studi lapangan yang digunakan dalam penelitian ini adalah kuisoner. Kuisoner yang dibagikan kepada karyawan PT BPRS Artha Madani berisi pertanyaan yang meliputi hal-hal yang fakta dan juga tentang persepsi responden. Yang merupakan kumpulan data untuk diolah, dianalisa dan ditarik kesimpulannya.

\section{Teknik Sampling}

Yang menjadi obyek penelitian ini adalah karyawan PT BPRS Artha Madani bagian merketing 15 orang. Jumlah karyawan PT BPRS Artha Madani adalah 53 orang. Unit analisis dalam penelitian adalah analisis kredit terhadap persetujuan pembiayaan yang berhubungan dengan merketing pembiayaan.

1. Populasi

Menurut Husaini Usman (2011:42), populasi adalah semua nilai baik hasil perhitungan maupun pengukuran baik kuantitatif maupun kualitatif daripada karakteristik tertentu mengenai sekelompok objek yang lengkap dan jelas. Dengan demikian yang menjadi populasi penelitan ini adalah seluruh bagian marketing PT BPRS Artha Madani.

2. Sampel

Menurut Husaini Usman (2011:43),sampel adalah sebagian anggota populasi yang diambil dengan menggunakan teknik tertentu yang disebut dengan teknik sampling.Sedangkan Suharsini Arikunto (1993:120) menerangkan bahwa untuk sekedar ancer-ancer apabila subjek yang diteliti kurang dari 100, lebih baik diambil semua sehingga penelitiannya merupakan penelitian populasi, sedangkan jika lebih dari 100 maka lebih baik diambil antara 10\%-15\% atau 20\%-25\% atau lebih". Populasi yang menjadi objek penelitian ini berjumlah 15 karyawan, maka penulis memilih mengambil seluruh karyawan yang berjumlah 15 karyawan karena dibawah 100 karyawan.

\section{Teknik Analisis Data}

Teknik Analisis Data adalah metode ilmiah dimana penulis berusaha menganalisis data yang suda didapat dengan menggunakan teori-teori yang sudah ada. Untuk mengetahui pelaksanaan pemberian motivasi dan kepuasan kerja maka digunakan angka penafsiran dengan rumus sebagai berikut :

$$
M=\sum f(x) / n
$$


Keterangan :

$M=$ perolehan angka penafsiran

$\mathrm{f}=$ frekuensi jawaban

$\mathrm{x}=$ pembobotan (skala nilai)

$\sum$ = penjumlahan

$\mathrm{N}$ = jumlah seluruh jawaban

Untuk menilai hasil jawaban dari setiap pernyataan dalam kuesioner, digunakan metode skala Likert dari pembobotan dari $1 \mathrm{~s} / \mathrm{d} 5$.

Koefisien korelasi ( $\mathrm{r}$ ) dihitung dengan menggunakan rumus product moment:

Untuk menyatakan besar kecilnya sumbangan variabel $\mathrm{X}$ terhadap $\mathrm{Y}$ dapat ditentukan dengan rumus koefisien diterminan dengan rumus:

$\mathrm{KP}=\mathbf{r}^{2} \mathbf{x} 100 \%$

Keterangan:

KP : Nilai koefisien diterminan

$\mathrm{r} \quad$ : Nilai koefisien korelasi

Uji signifikan yang dilakukan dengan uji $\mathrm{t}$, dimana jika $\mathrm{Ho}=\mathrm{t}$ hitung $<\mathrm{t}$ tabel, maka hipotesis nol (Ho) diterima atau hipotesis alternatif $\left(\mathrm{H}_{1}\right)$

Selanjutnya untuk menginterprestasi tingkat hubungan dengan variabel bebas dengan variabel terikat, maka penulis memakai pedoman sebagai berikut :

Tabel 1.

Skala Interval Koefisien Korelasi

\begin{tabular}{|c|c|}
\hline INTERVAL KOEFISIEN & TINGKAT HUBUNGAN \\
\hline $0,00-0,199$ & Sangat Rendah \\
$0,20-0,399$ & Rendah \\
$0,40-0,599$ & Sedang \\
$0,60-0,799$ & Kuat \\
$0,80-1,00$ & Sangat Kuat \\
\hline
\end{tabular}

Sumber : Sugiyono (2007)

\section{Lokasi dan Jadwal Penelitian}

Penelitian mengambil lokasi PT Bank Pembiayaan Syariah Artha Madani (BPRS) Artha Madani yang berlokasi di Jalan Industri no. 57 Cikarang kabupaten Bekasi. Adapun waktu yang dibutuhkan penulis dalam penyelesaian skripsi ini adalah dari bulan April 2013 sampai dengan Juli 2013.

\section{Sejarah Singkat Perusahaan}

PT Bank Pembiayaan Syariah Artha Madani (BPRS) Artha Madani yang berlokasi di Jalan Industri no. 57 Cikarang kabupaten Bekasi. PT BPRS Artha Madani didirikan berdasarkan akte nomor 58 tanggal 06 April 2005 dibuat dihadapan Arry Supratno, S.H, Notaris Jakarta Pusat. Anggaran dasar tersebut telah mengalami perubahan disesuaikan dengan UU No. 40/2007, tentang perseroan terbatas. Dalam akta perubahan anggaran dasar nomor 32 tertanggal 13 februari 2008 yang dibuat dihadapan Ruly Dewanti, S.H, Notaris di kabupaten Bekasi. Anggaran dasar beserta perubahannya tersebut diatas telah memperoleh pengesahan dari Menteri Hukum dan Hak Asasi Manusia nomor : AHU25378.AH.01.02 tahun 2008 tertanggal 14 Mei 2008.

Anggaran dasar perseroan beberapa kali telah mengalami perubahan, yaitu dengan akta No. 01 tanggal 04 November 2009 dari Notaris Ruly Dewanti, SH, mengenai perubahan nama perseroan menjadi PT Bank Pembiayaan Rakyat Syariah Artha Madani dan peningkatan modal disetor. Perubahan terakhir dengan akta No.08 tanggal 11 agustus 2010, dari Notaris Ruly Dewanti, SH, mengenai perubahan susunan dewan direksi dan dewan komisaris serta peningkatan modal disetor 
ditempatkan dan perubahan komposisi pemegang saham. Perubahan anggaran dasar perusahaan telah diterima dan dicatat didalam database Sistem Administrasi Badan Hukum Kementrian Hukum dan Hak Asasi Manusia Republik Indonesia Nomor:AHU-069893.AH.01.09 tahun 27 September 2010.

PT BPRS Artha Madani menempati gedung sendiri dan merupakan holding company dari perusahaan penunjang di antaranya:

a. Usaha Dagang Ria Jaya Motor (Show Room Mobil)

Usaha ini meliputi jual beli mobil baru dan bekas yang berlokasi Cikarang dan Cikampek.

b. Kampus LP3I Cikarang

Yang berlokasi di Cikarang dan mulai berdiri pada tahun 2006. LP3I Cikarang memiliki 4 jurusan untuk pilihan mahasiswa berkuliah, diantaranya : manajemen perkantoran, komputer akuntansi, teknik informatika dan bisnis administrasi.

c. Purwacaraka Music Studio Padang

Sekolah musik yang berlokasi di Padang Sumatera Barat dan beroperasi mulai tahun 2007.

d. Kontraktor Kendaraan Angkut Batu Bara

Kendaraan angkut batu bara yang disewakan kepada perusahaan pengelola batu bara yang berlokasi di Kabupaten Tanah Bumbu Batu Licin Kalimantan Selatan dan beroperasi dari bulan Februari 2008.

e. Salon Bali Ungu

Salon \&Day Spayang dikhusukan untuk wanita dan sudah memiliki 2 cabang di Jababeka Cikarang dan Lippo Cikarang. Beroperasi dari tahun 2009

f. Restoran Sederhana Balingka

Yang beroperasi pada bulan Oktober 2010, melayani pesan antar makanan dan menyediakan tempat untuk acara rapat atau lainnya.

\section{HASIL PNELITIAN}

\section{Kondisi Umum Responden}

Data responden yang menjadi sampel tersebut dapat dilihat pada tabel 2 sampai dengan tabel 5 .

Tabel 2. Perbandingan Jumlah Responden Berdasarkan Jenis Kelamin

\begin{tabular}{|c|c|c|}
\hline Jenis Kelamin & Responden & $\%$ \\
\hline Laki-laki & 8 & 53,33 \\
\hline Perempun & 7 & 46,67 \\
\hline Total & 15 & 100 \\
\hline
\end{tabular}

Sumber : Data SDI dan Umum, Juni 2013

Tabel 3. Perbandingan Jumlah Responden Berdasarkan Usia

\begin{tabular}{|c|c|c|c|c|c|c|}
\hline \multirow{2}{*}{ Usia } & \multicolumn{2}{|c|}{ Laki-laki } & \multicolumn{2}{|c|}{ Perempuan } & \multicolumn{2}{|c|}{ Total } \\
\hline & $\mathbf{J m l}$ & $\%$ & Jml & $\%$ & $\mathbf{J m l}$ & $\%$ \\
\hline 25 tahun ke bawah & 0 & - & 3 & $42,86 \%$ & 3 & $20 \%$ \\
\hline 25 s.d 30 tahun & 4 & $50 \%$ & 4 & $57,14 \%$ & 8 & $53,33 \%$ \\
\hline 35 s.d 40 tahun & 4 & $50 \%$ & 0 & - & 4 & $26,67 \%$ \\
\hline Total & 8 & 100 & 7 & 100 & 15 & 100 \\
\hline
\end{tabular}

Sumber : Data SDI dan Umum, Juli 2013 
Tabel 4. Perbandingan Jumlah Responden Berdasarkan Status Pernikahan

\begin{tabular}{|c|c|c|c|c|c|c|}
\hline \multirow{2}{*}{ Status Pernikahan } & \multicolumn{2}{|c|}{ Laki-laki } & \multicolumn{2}{c|}{ Perempuan } & \multicolumn{2}{c|}{ Total } \\
\cline { 2 - 7 } & Jml & $\%$ & Jml & $\%$ & Jml & $\%$ \\
\hline Belum Menikah & 2 & $25 \%$ & 2 & $28,57 \%$ & 4 & $26,67 \%$ \\
\hline Menikah & 6 & $75 \%$ & 5 & $71,43 \%$ & 11 & $73,33 \%$ \\
\hline \multirow{2}{*}{ Total } & $\mathbf{8}$ & 100 & $\mathbf{7}$ & $\mathbf{1 0 0}$ & $\mathbf{1 5}$ & 100 \\
\hline
\end{tabular}

Sumber : Data SDI dan Umum, Juni 2013

Tabel 5. Perbandingan Jumlah Responden Berdasarkan Tingkat Pendidikan

\begin{tabular}{|c|c|c|c|c|c|c|}
\hline \multirow{2}{*}{ Pendidikan } & \multicolumn{2}{|c|}{ Laki-laki } & \multicolumn{2}{|c|}{ Perempuan } & \multicolumn{2}{|c|}{ Total } \\
\hline & Jmlh & $\%$ & Jmlh & $\%$ & Jmlh & $\%$ \\
\hline SMA & 1 & $12,5 \%$ & - & - & 1 & $6,67 \%$ \\
\hline D3 & 2 & $25 \%$ & 4 & $\begin{array}{c}57,14 \\
\%\end{array}$ & 6 & $40 \%$ \\
\hline S1 & 5 & $62,5 \%$ & 3 & $\begin{array}{c}42,86 \\
\%\end{array}$ & 8 & $53,33 \%$ \\
\hline Total & 8 & 100 & 7 & 100 & 15 & 100 \\
\hline
\end{tabular}

Sumber :Data SDI dan Umum, Juni 2013

\section{Analisis Kredit}

Hasil rekapitulasi data analisi kredit ditampilkan sebagai berikut :

Tabel 6. Rekapitulasi Indikator Variabel X (Analisis Kredit)

\begin{tabular}{|c|c|c|c|}
\hline No. & Indikator & $\mathbf{M}$ & Kriteria \\
\hline 1 & Kepercayaan Kreditur & 3,73 & Baik \\
\hline 2 & Karakter Calon Debitur & 4,06 & Baik \\
\hline 3 & Personality Debitur & 4,33 & Baik \\
\hline 4 & Aspek Keuangan & 4,53 & Sangat Baik \\
\hline 5 & Jaminan & 4,40 & Sangat Baik \\
\hline 6 & Nilai Jaminan & 4,13 & Baik \\
\hline 7 & Mudah & 4,00 & Baik \\
\hline 8 & Penggunaan Pembiayaan & 3,67 & Baik \\
\hline 9 & Cepat & 3,33 & Cukup Baik \\
\hline 10 & Akurat & 3,87 & Baik \\
\hline \multicolumn{2}{|r|}{ Jumlah } & 40,05 & \\
\hline \multicolumn{2}{|r|}{ Rata-Rata } & 4,01 & Baik \\
\hline
\end{tabular}

Sumber : Penelitian Tahun 2013 
Dari hasil rekapitulasi tabel diatas didapat kesimpulan angka penafsiran 4,01 dengan penilaian baik. Artinya analisis kredit dilakukan oleh karyawan bagian marketing pada PT BPRS Artha madani berdasarkan indikator dari variabel yang diperoleh dari jawaban responden adalah baik.

\section{Analisis Persetujuan Pembiayaan}

Hasil rekapitulasi data analisis kredit, selengkapnya dapat dilihat pada table berikut

Tabel 7. Rekapitulasi Indikator Variabel Y (Persetujuan Pembiayaan)

\begin{tabular}{|c|c|c|c|}
\hline No. & Indikator & M & Kriteria \\
\hline 1 & $\begin{array}{c}\text { Meningkatkan ketelitian } \\
\text { pada usulan pembiayaan }\end{array}$ & 4,93 & Sangat Baik \\
\hline 2 & $\begin{array}{c}\text { Melihat itikad baik dari } \\
\text { calon debitut }\end{array}$ & 4,47 & Sangat Baik \\
\hline 3 & $\begin{array}{c}\text { Melihat kepribadian calon } \\
\text { debitur }\end{array}$ & 3,87 & Baik \\
\hline 4 & $\begin{array}{c}\text { Menganalisis keuangan } \\
\text { calon debitur }\end{array}$ & 4,53 & Sangat Baik \\
\hline 5 & $\begin{array}{c}\text { Mensurvei keadaan calon } \\
\text { debitur }\end{array}$ & 3,20 & Cukup Baik \\
\hline 6 & $\begin{array}{c}\text { Kemudahan pesyaratan } \\
\text { untuk calon debitur }\end{array}$ & 4,00 & Baik \\
\hline 7 & $\begin{array}{c}\text { Penggunaan pembiayaan } \\
\text { oleh calon debitur }\end{array}$ & 3,40 & Cukup Baik \\
\hline 8 & $\begin{array}{c}\text { Kecepatan Menangani } \\
\text { Nasabah }\end{array}$ & 3,67 & Baik \\
\hline 9 & Data dari calon debitur & 3,80 & Baik \\
\hline 10 & Prosedur Pembiayaan & 4,27 & Sangat Baik \\
\hline \multicolumn{2}{|c|}{ Jumlah } & $\mathbf{4 0 , 1 4}$ & Baik \\
\hline
\end{tabular}

Sumber : Penelitian Tahun 2013

Setelah diperoleh angka penafsiran untuk setiap pertanyaan (indikator), penulis membuat rekapitulasi semua indikator untuk variabel Y (Persetujuan Pembiayaan) seperti pada tabel 4.26 dibawah ini, dan terlihat nilai rekapitulasi dari variabel Y sebesar 4,01 yang berarti secara keseluruhan variabel persetujuan pembiayaan dikategorikan baik.

Selanjutnya untuk mengetahui ada atau tidak hubungan didalam variabel bebas (analisis kredit) dengan variabel terikat (persetujuan pembiayaan) maka digunakan metode analisis product moment Pearson sebagai berikut :

Tabel 8. Tabel Uji Korelasi Variabel X dan Variabel

\begin{tabular}{|c|c|c|c|c|c|}
\hline \multicolumn{7}{|c|}{ Uji Korelasi Product Moment Reason } \\
\hline Responden & $\mathbf{X}$ & $\mathbf{Y}$ & $\mathbf{X}^{\mathbf{2}}$ & $\mathbf{Y}^{\mathbf{2}}$ & $\mathbf{X ~ Y}$ \\
\hline 1 & 40 & 38 & 1600 & 1444 & 1520 \\
\hline 2 & 35 & 37 & 1225 & 1369 & 1295 \\
\hline 3 & 40 & 42 & 1600 & 1764 & 1680 \\
\hline 4 & 38 & 40 & 1444 & 1600 & 1520 \\
\hline 5 & 40 & 42 & 1600 & 1764 & 1680 \\
\hline 6 & 40 & 39 & 1600 & 1521 & 1560 \\
\hline 7 & 36 & 37 & 1296 & 1369 & 1332 \\
\hline 8 & 41 & 41 & 1681 & 1681 & 1681 \\
\hline 9 & 42 & 40 & 1764 & 1600 & 1680 \\
\hline 10 & 45 & 44 & 2025 & 1936 & 1980 \\
\hline 11 & 44 & 42 & 1936 & 1764 & 1848 \\
\hline 12 & 41 & 39 & 1681 & 1521 & 1599 \\
\hline 13 & 40 & 40 & 1600 & 1600 & 1600 \\
\hline 14 & 40 & 37 & 1600 & 1369 & 1480 \\
\hline 15 & 39 & 40 & 1521 & 1600 & 1560 \\
\hline Total & $\mathbf{6 0 1}$ & $\mathbf{5 9 8}$ & $\mathbf{2 4 1 7 3}$ & $\mathbf{2 3 9 0 2}$ & $\mathbf{2 4 0 1 5}$ \\
\hline
\end{tabular}


Hasil uji signifikan antara variabel $\mathrm{X}$ (analisis kredit) dengan variabel $\mathrm{Y}$ (persetujuan pembiayaan). Menujukkan bahwa berdasarkan hasil perhitungan $\mathrm{t}_{\text {hitung }}$ adalah 6,852 dengan $\mathrm{t}$ tabel $\mathrm{dk}$ $(\mathrm{n}-2)=8$, pada 0,05 maka, $\mathrm{t}_{\text {tabel }}$ adalah sebesar 2,160. Dengan demikian $\mathrm{t}_{\text {hitung }}$ lebih besar dari $\mathrm{t}_{\text {tabel }}$ $(6, .852>2,160)$. Sesuai dengan kriteria pengujian maka kondisi yang demikian membawa kepada kesimpulan hipotesis nol $\left(\mathrm{H}_{\mathrm{o}}\right)$ ditolak atau hipotesis alternatif $\left(\mathrm{H}_{1}\right)$ diterima. Hal ini berarti ada hubungan antara analisis kredit terhadap persetujuan pembiayaan di PT BPRS Artha Madani.

Selanjutnya untuk melihat besarnya kontribusi variabel $\mathrm{X}$ terhadap variabel $\mathrm{Y}$ dapat digunakan rumus sebagai berikut:

Dari hasil penelitian ini diperoleh nilai $\mathrm{r}$ adalah 0,728 sehingga besarnya kontribusi variabel $\mathrm{X}$ terhadap varabel $\mathrm{Y}$ adalah sebagai berikut :

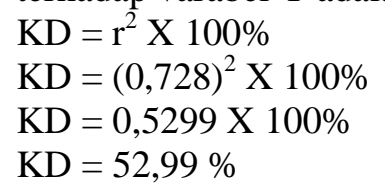

Berdasarkan hasil perhitungan nilai Koefisien Determinasi, diperoleh nilai kontribusi variabel X terhadap variabel $\mathrm{Y}$ adalah sebesar 52,99\%. Nilai 52,99\% menunjukan bahwa analisis kredit memberikan nilai kontribusi cukup besar yaitu $52,99 \%$ terhadap persetujuan pembiayaan dan $47,01 \%$ menunjukan bahwa ada variabel lain yang mempengaruhi.

\section{PEMBAHASAN}

\section{Persyaratan Pembiayaan Calon Debitur}

Data yang diperlukan oleh Account officer bank berdasarkan pada kebutuhan dan tujuan pembiayaan. Untuk pembiayaan konsumtif, data yang diperlukan adalah data yang dapat menggambarkan kemampuan nasabah untuk membayar pembiayaan dari penghasilan tetapnya. Data yang diperlukan antara lain:

1. Untuk Pegawai Negeri Sipil (PNS)
a. Kartu identitas calon nasabah dan istri, Kartu Tanda Penduduk (KTP).
b. Kartu Keluarga (KK) dan surat nikah.
c. Pas photo $3 \times 4$ suami istri
d. Copy taspen dan copy karpeg.
d. Copy SK $80 \%$ dan $100 \%$.
e. SK Asli golongan atau pangkat terakhir.
f. Legal gaji dan tunjangan daerah.

2. Untuk pengusaha perorangan atau UKM
a. Kartu identitas calon nasabah dan istri (KTP).
b. Kartu Keluarga dan surat nikah.
c. Surat Izin Usaha Perdagangan (SIUP).
d. Nomor Pokok Wajib Pajak (NPWP).
e. Data obyek pembiayaan.
f. Salinan tagihan rekening listrik dan telepon 3 (tiga) bulan terakhir.
g. Sertifikat Hak Milik / BPKB.
h. STNK (masa pajak masih berlaku).
i. Slip gaji (bagi karyawan) SK pengangkatan tetap.

\section{Prosedur pembiayaan}

Pengajuan permohonan kredit harus dilakukan secara tertulis oleh calon debitur baik melalui surat atau dengan cara mengisi formulir. Berikut ini adalah prosedur pengajuan pembiayaan oleh calon debitur pada PT BPRS Artha Madani:

1. Mengisi formulir permohonan pembiayaan yang disediakan di Customer Service.

2. Melampirkan foto copy legalitas, jaminan dan dokumen lain yang diperlukan.

3. Melakukan survei langsung dan analisis oleh pihak bank.

4. Melakukan pengecekan calon debitur melalui SID (Sistem Informasi Debitur).

5. Menunggu konfirmasi penerimaan atau penolakan pengajuan. 
6. Melakukan akad perjanjian pembiayaan dan pengikatan jaminan.

7. Pencairan dana.

\section{Produk Pembiayaan}

a. Pembiayaan Murabahah

Bank syariah sebagai penjual dan nasabah sebagai pembeli. Kemudian bank menjualnya kembali kepada pembeli dengan harga beli ditambah margin yang telah disepakati.

b. Pembiayaan Musyarakah

Kerja sama dalam suatu usaha oleh dua pihak dengan ketentuan umum. Pengembalian hasil usaha tergantung kepada nisbah bagi hasil yang disepakati nasabah dan bank. Semakin tinggi kinerja usaha nasabah, semakin tinggi pula bagi hasil untuk masing-masing pihak.

c. Al- Qard Karyawan

Digunakan untuk membantu keuangan nasabah khususnya karyawan secara cepat dan berjangka pendek (short time)

d. Gadai Syariah

Untuk memberikan jaminan pembayaran kembali kepada bank dalam memberikan pembiayaan.

Barang yang digadaikan wajib memenuhi kriteria diantaranya:

1. Diutamakan emas.

2. Milik nasabah sendiri.

3. Jelas ukuran.

4. Sifat dan nilainya ditentukan berdasarkan nilai riil pasar.

e. Pembiayaan Kolektif (PNS)

Pembiayaan ini bersifat murabahah dan bekerjasama dengan bendahara dinas-dinas. Pembiayaan ini bersifat kolektif sistem pembayaran dipotong gaji oleh bendahara.

f. Pembiayaan Sertifikasi

Pembiayaan ini menggunakan jaminan berupa tabungan dan ATM debitur. Sistem pembayaran angsuran dengan menarik ATM debitur setiap dana sertifikasi turun.

\section{Aspek Aspek Penilaian Pembiayaan}

Aspek penilaian pada pemberian pembiayaan pada PT BPRS Artha Madani menggunakan 5C (Character, Capital, Capacity, Condition, Collateral). Dan pada usulan pembiayaan melampirkan 6A (Aspek Yuridis, Aspek Pasar, Aspek Keuangan, Aspek Teknis, Aspek Manajemn, Aspek Sosial Ekonomi).

\section{Analisis Pembiayaan}

Analisis pembiayaan yang diterapkan pada PT BPRS Artha Madani dapat dilihat pada aplikasi pembiayaan. Aplikasi pembiayaan terdiri dari:

a. Latar belakang calon debitur harus sesuai dengan kartu identitas calon debitur.

b. Riwayat calon debitur harus dipaparkan secara jelas dan menjalankan usaha atau pekerjaan yang dilakukan saat ini.

c. Analisa pembiayaan ditinjau dari 5 C (Character, Capacity, Capital, Condition, Collateral).

d. Analisis pendapatan bersih perbulan

Pada aplikasi pembiayaan Ali Muhidin terdapat laporan keuangan bulan Mei 2013 sebagai berikut:

Pendapatan usaha : Rp 50,000,000

Biaya-Biaya Usaha :

B.Gaji karyawan $\quad$ Rp 7,700,000

B. Sewa kendaraan Rp 4,000,000

B. Perawatan alat Rp $1,750,000$

B. Transportasi Rp 2,500,000

B. Listrik Rp 850,000

B. Telepon Rp $1,170,000$

B.Penyusutan Rp 2,250,000

B. Lain-lain $\quad$ Rp 5,900,000

Total Biaya $\quad$ Rp 26,455,000 
Pendapatan Usaha

Gaji Istri

Total Pendapatan
Rp 23,545,000
Rp 9,007,600
Rp 32,552,600

Biaya - biaya :

B.Rumah tangga

Angsuran Bank lain

Angsuran BPRS

Total Biaya

Pendapatan Bersih

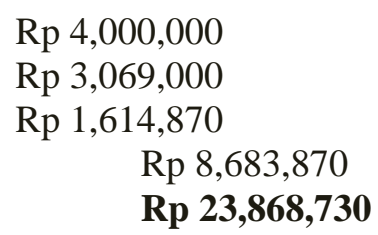

Pembiayaan murabahah Rp 90,000,000 jangka waktu 60 bulan, angsuran perbulan Rp 3,075,000.

Analisis perbadingan cicilan sebagai berikut:

Terhadap penghasilan yang dapat digunakan

Angsuran perbulan $=\operatorname{Rp~3,075,000}$

Pendapatan bersih $\operatorname{Rp} 23,868,730=12,88 \%$

Terhadap pendapatan setiap bulan

Angsuran perbulan $=\operatorname{Rp~3,075,000~}$

Total Pendapatan Rp 32,552,600 = 9,44\%

Jaminan dan legalitas

Jaminan berupa SHGB No. 8327 nilai jaminan sudah di appraisal oleh kantor jasa penilai publik iskandar asmawi dan rekan.

Harga tanah : $90 \mathrm{~m}^{2} \quad=\mathrm{Rp} 58,500,000$

Harga Bangunan : $63 \mathrm{~m}^{2} \quad=\mathrm{Rp} 75,800,000$

Total jaminan $=R p$ 134,300,000

Nilai taksasi jaminan:

Rp 134,300,000 x $80 \%=\operatorname{Rp} 107,440,000$

\section{Hubungan Analisis Kredit Terhadap Persetujuan Pembiayaan}

Dari hasil penelitian pada uji korelasi product moment adalah 0,728 sesuai dengan interpretasi koefisien relasi menurut Suigiyono (2007), maka koefisien relasi variabel X dan Y inin menunjukan interpretasi yang kuat.

\section{Pengembalian kredit diawal}

Tabel 9. pembiayaan murabahah bulan April 2013

\begin{tabular}{|l|r|r|r|}
\hline Jangka & Jumlah & \multicolumn{1}{c|}{ Jumlah } & Presentase \\
Waktu & Debitur & \multicolumn{1}{c|}{ Piutang } & \\
\hline$<1$ tahun & 294 & 5.743 .321 .669 & 12,82 \\
\hline $1-2$ tahun & 168 & 5.271 .916 .522 & 11,77 \\
\hline$>2-5$ tahy & 529 & 31.241 .009 .247 & 69,73 \\
\hline$>5$ tahun & 33 & 2.547 .698 .568 & 5,68 \\
\hline Total & $\mathbf{1 0 2 4}$ & $\mathbf{4 4 . 8 0 3 . 9 4 6 . 0 0 6}$ & $\mathbf{1 0 0}$ \\
\hline
\end{tabular}


Tabel 9 pembiayaan musyarakah bulan April 2013

\begin{tabular}{|l|r|r|r|}
\hline $\begin{array}{l}\text { Jangka } \\
\text { Waktu }\end{array}$ & \multicolumn{1}{l|}{ Dumlah } & \multicolumn{1}{l}{$\begin{array}{l}\text { Jumlah } \\
\text { Pebitur }\end{array}$} & Presentase \\
\hline$<1$ tahun & 22 & 8.270 .000 .000 & 100 \\
\hline $1-2$ tahun & 0 & - & 0 \\
\hline Total & $\mathbf{2 2}$ & $\mathbf{8 . 2 7 0 . 0 0 0 . 0 0 0}$ & $\mathbf{1 0 0}$ \\
\hline
\end{tabular}

Berdasarkan ketentuan perhitungan pelunasan sebelun jatuh tempo memo internal No. 064/IM/DIR_BSAM/01/2013 adalah sebagai berikut:

Untuk nasabah pembiayaan kolektif yang melakukan pelunasan diawal maka ketentuannya adalah:

a. Angsuran 1-6 bulan dikenakan 3 margin bulan berjalan

b. Angsuran diatas 6 bulan dikenakan 2 bulan berjalan

Untuk nasabah pembiayaan UKM yang melakukan pelunasan diawal maka ketentuannya adalah:

a. Angsuran 1-6 bulan dikenakan 3 bulan berjalan

b. Angsuran diatas 6 bulan dikenakan 2 bulan berjalan.

\section{KESIMPULAN DAN SARAN}

\section{Kesimpulan}

Berdasarkan hasil penelitian yang penulis lakukan, maka dapat disimpulkan sebagai berikut :

1. Besarnya tanggapan responden terhadap variabel analisis kredit menunjukkan angka sebesar 4,01 yang berarti analisis kredit pada PT BPRS Artha Madani sudah berjalan baik.

2. Dan besarnya tanggapan responden terhadap variabel persetujuan pembiayaan menunjukan angka penafsiran sebesar 4,01 yang berarti secara keseluruhan variabel terikat dikategorikan baik.

3. Koefisien $\mathrm{r}$ yang didapat adalah 0,728 dan nilai ini menunjukan hubungan variabel $\mathrm{x}$ (analisis kredit) dengan variabel y (persetujuan pembiayaan) adalah kuat.

\section{Saran}

Berdasarkan kesimpulan di atas, maka saran yang penulis ajukan adalah sebagai berikut :

1. Diharapkan agar setiap proposal kredit yang masuk harus dianalisis seteliti mungkin agar terhindar dari kredit macet. Tidak mengabaikan analisis 5C (Character, Capacity, Capityal, Condtion, Collateral). Dan dapat meminimalisir pembiayaan bermasalah dengan cara terus memantau perkembangan debitur.

2. Pihak management harus lebih teliti dalam memeriksa kelengkapan persyaratan pengajuan pembiayaan. Menyetujui pembiayaan yang dicairkan harus dapat dipertanggung jawabkan.

\section{DAFTAR PUSTAKA}

Anonim. 2002. Undang-Undang No. 10 Tahun 1998 Tentang PerubahanUndang-Undang No. 7 ahun 1992, Jakarta: Sinar Grafika

Arikunto, Suharsimi. 1993. Prosedur Penelitian: Suatu Pendekatan Praktek. Rineka Cipta: Jakarta

Djohan, Warman. 2000. Kredit Bank, Edisi 1. PT. Mutiara Sumber Widya: Jakarta

Hasibuan Malayu.2007. Dasar-dasar Perbankan, Edisi kelima. Jakarta: Bumi Aksara Jusuf Jopie.2007. Analisis Kredituntuk officer, Edisi kedelapan. Jakarta: PT Gramedia Pustaka Utama

Husaini, Usman (2011). Motivasi Dalam Bekerja Karyawan. Jakarta: PT. Gramedia Widiasarana Indonesia

Kasmir. 2003. Bank Dan Lembaga Keuangan lainnya. Jakarta: PT Raja Grafindo Persada

Kasmir. 2010. Dasar-dasar Perbankan, Edisi 1-8. Jakarta: Rajawali Pers

Sugiyono. 2003. Metode Penelitian Administrasi. Bandung : CV Alfabeta

Suyatno, Thomas, 2003, Dasar-Dasar Perkreditan, PT. Gramedia Pustaka. Utama, Jakarta. 